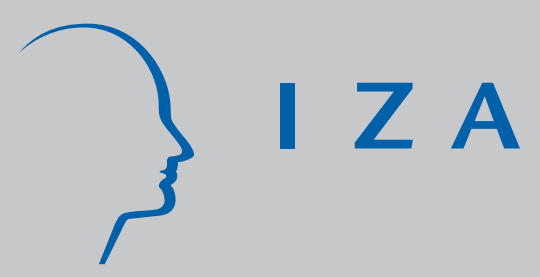

IZA DP No. 875

Severance Payments for Dismissed

Employees in Germany

Christian Grund

September 2003 


\title{
Severance Payments for Dismissed Employees in Germany
}

\author{
Christian Grund \\ University of Bonn \\ and IZA Bonn
}

\section{Discussion Paper No. 875 September 2003}

\author{
IZA \\ P.O. Box 7240 \\ D-53072 Bonn \\ Germany \\ Tel.: +49-228-3894-0 \\ Fax: +49-228-3894-210 \\ Email: iza@iza.org
}

This Discussion Paper is issued within the framework of IZA's research area Welfare State and Labor Market. Any opinions expressed here are those of the author(s) and not those of the institute. Research disseminated by IZA may include views on policy, but the institute itself takes no institutional policy positions.

The Institute for the Study of Labor (IZA) in Bonn is a local and virtual international research center and a place of communication between science, politics and business. IZA is an independent, nonprofit limited liability company (Gesellschaft mit beschränkter Haftung) supported by Deutsche Post World Net. The center is associated with the University of Bonn and offers a stimulating research environment through its research networks, research support, and visitors and doctoral programs. IZA engages in (i) original and internationally competitive research in all fields of labor economics, (ii) development of policy concepts, and (iii) dissemination of research results and concepts to the interested public. The current research program deals with (1) mobility and flexibility of labor, (2) internationalization of labor markets, (3) welfare state and labor market, (4) labor markets in transition countries, (5) the future of labor, (6) evaluation of labor market policies and projects and (7) general labor economics.

IZA Discussion Papers often represent preliminary work and are circulated to encourage discussion. Citation of such a paper should account for its provisional character. A revised version may be available on the IZA website (www.iza.org) or directly from the author. 
IZA Discussion Paper No. 875

September 2003

\section{ABSTRACT}

\section{Severance Payments for Dismissed Employees in Germany}

This contribution investigates severance payments for dismissed employees in Germany. Subsequent to an overview about the legal framework, we respond to the following questions: Who receives severance payments? By which characteristics is the level of severance payments determined? Is overcompensation to be considered a relevant issue? Hereby, individual and collective dismissals are always distinguished. This is the first study on this issue using individual representative data - the German Socio-Economic Panel - and multivariate methods. The results indicate that rather women, persons with many years of tenure and working in big firms receive severance payments. There is a huge variance in the size of the payments, which can only partly be explained by tenure, the wage, firm size and the region. At least one quarter of dismissed employees is better off in their following careers independent of having received a severance payment.

JEL Classification: M51, M52, J32, J53

Keywords: $\quad$ severance payments, dismissals, plant closings

\section{Christian Grund}

BWL II

Department of Economics

University of Bonn

Adenauer Allee 24-42

53113 Bonn

Germany

Tel.: +49 228739213

Fax: +49 228739210

Email: christian.grund@uni-bonn.de 


\section{Severance Payments for Dismissed Employees in Germany}

\section{Introduction}

In 2000 the British Vodafone Group acquired the German Mannesmann AG, what resulted in a redundancy of Mannesmann CEO Klaus Esser, inter alia. However, the financial consequences for Klaus Esser were not too bad: he received a totalling severance payment of over $€ 30,000,000$. This 'golden parachute' was approved by the board of directors and justified with Esser's success in increasing the shareholder value of the Mannesmann AG (see Financial Times Deutschland 2000).

Obviously, there are other rules to define whether ordinary employees other than top managers receive severance payments in the case of dismissals and how to fix their size. Apart from the above mentioned prominent case, astonishingly little is known about severance payments for individually or collectively dismissed employees in Germany. The legal framework is not very explicit with respect to this issue and there are only few and not very updated studies, which concentrate on decisions of labour courts and severance payments in connection with social plans in firms with mass layoffs (see Falke et al. 1981, Falke 1983, Hemmer 1997a).

The aim of this study is therefore to analyse the relevance of severance payments in Germany. Both, the probability and the size of severance payments, are examined. We make use of the German Socio-Economic Panel (GSOEP), a large representative data set, which has not been consulted for this issue before. 
What do we know about severance payments in general? Several studies examine the effects of severance payments on aggregated employment and unemployment as well as on firm and individual behaviour: Using aggregated data from more than 20 countries during the years 1956 to 1984 Lazear (1990) finds evidence for employment reductions of severance pay requirements in Europe. Addison and Grosso (1996) as well as Addison et al. (2000) relativise this result. Within a more detailed analysis they find no significant effect of severance payments on the unemployment rate. ${ }^{1}$ Additionally, Hunt (2000) investigates that the reduction of firing costs - especially severance payments by a modification of the legal requirements in 1985 had no effect on the speed of employment adjustment in Germany.

As to the effects on individual behaviour, Krodrzycki (1998) ascertains that severance recipients in Massachusetts, where the severance bonuses are paid in addition to unemployment insurance benefits, return to work more slowly. Also, the probability of quits increases, if severance payments are announced for employee initiated separations as well. Pencavel (2001) examines this effect for the case of the University of California's faculty. Kugler (2002) analyses the legal framework of Columbia, where in 1990 a new system of individual severance payments saving accounts (SPSA) replaced the former mandatory severance pay for dismissed employees in the amount of one monthly wage per year of tenure. It is shown that the system of SPSA makes it easier for the firms to shift the costs of severance payments to the workers in form of lower wages. It is important to note that within a perfect market mandated severance payments can be offset by a properly designed contract, e.g. by an up-front payment from the worker to the firm (see Lazear 1990: 699). But as soon as market imperfections such as

\footnotetext{
${ }^{1}$ Other studies concentrate on the consequences of general dismissal protection regulations on employment, unemployment as well as entries in and outflows from unemployment. For instance, general results of Jackman et al. (1996), Nickel (1997), Nickel and Layard (1999) and the OECD (1999) include decreasing short term unemployment, increasing long term unemployment and lowering of the adaptation speed by the degree of dismissal protection. Others such as Bertola (1990) and Blanchard and Wolfers (2000) find no effect on employment and unemployment. Boeri (1999) demonstrates that the employment chance for unemployed persons is reduced by dismissal protection.
} 
limited liability of employees or incomplete information are taken into account, this possibility does not endure any more.

Some contributions investigate the size of severance payments to dismissed employees on an aggregated level as well. Within a wider context, several contributions analyse adjustment costs - differentiated in hiring and firing costs. The results vary substantially among countries and industries (see e.g. Burda 1991). For instance, Del Boca and Rota (1998) estimate hiring costs of 2.0 to 2.6 months of labour costs and a huge range from 0.5 to 20 months of labour costs for firing costs in Italy. Hamermesh and Pfann (1996: 1280) and Hunt (2000: 181) provide brief overviews of the relevant literature. The few studies dealing with the size of individual severance payments in Germany are discussed in Section 2 below.

There are also different theoretical economic approaches dealing with severance payments. $^{2}$ For example, macroeconomic effects of a change of severance pay are explored by Burda (1992). Fabel (2002) analyses the effect of severance payments on the layoff decisions of firms and finds decreasing layoff rates for older employees if severance payments increase with seniority. Suedekum and Ruehmann (2003) focus on the effect of severance payments on the human capital accumulation of employed workers. In general, investments in firm-specific human capital are strengthened by severance payments. However, the penalty function of dismissals is weakened simultaneously. Goerke (2003) incorporates this point even more explicitly within an efficiency wage model assuming that severance payments in the case of collective dismissals are also given to shirkers. Galdon-Sanchez and Güell (2003) point out a double moral hazard problem in dismissal conflicts within an efficiency wage framework. If firing costs are higher in the case of redundancies compared to disciplinary dismissals, employers will always have an incentive to claim each dismissal

\footnotetext{
${ }^{2}$ The general seminal work dates back to Oi (1962), who characterised labour as a quasi-fixed factor and examines - among other things - a rational order of dismissals at redundancies.
} 
as a disciplinary one. On the other hand, workers have always an incentive to claim unfair dismissal in order to receive a (higher) severance payment. If information problems occur for a court, wrong decisions lead to the situation that some redundant employees do not receive severance payments and some other fairly dismissed employees by disciplinary reasons do receive severance payments.

Other authors provide bargaining models, where employees and employers ex ante bargain about wages and the amount of severance payments. Hence, the determination of the size of severance payments is in the spotlight of these contributions. For example, Booth (1995) und Pita (1997) obtain a full insurance of the employees as a result. In this sense, full insurance means constant marginal utility of the employees over the states. Fabel (1996) even finds cases of efficient overcompensation of employees within his ex ante bargaining model with labour cost minimising firms.

Malo (2000: 270f) points out that there is considerable empirical evidence of ex-post bargaining about severance payments in most European countries as well. In this sense "ex post" means that negotiations about severance payments begin subsequent to the perception of a negative shock. He provides a model, which fitted especially the Spanish institutional framework of individual dismissals. However, the German case is represented by ex-post bargaining very often as well, because unions are responsible for wage bargaining industry wide and works councils rather than unions can help employees to receive substantial severance payments, when dismissals occur. In another paper Malo presents an ex-post (Nash-) bargaining model representing collective dismissals in continental Europe (see Malo 2001). One of the important results is again an overcompensation of the dismissed employees. Malo (2001: 84-86), as well as Fabel (1996: 592), tries to find some evidence of overcompensation that is in line with these theoretical considerations. Fabel argues on the basis of average severance payments in Germany and Malo gives a numerical example, using aggregated averages of severance 
payments and wages in Spain. A first direct empirical examination, using individual data - missing so far -, is given in this contribution (subsection 3.4).

At least the ex-ante bargaining models implicitly presume an insurance function of severance payments. Severance payments are supposed to act as insurance benefits against uncertain employment conditions. In this sense, severance payments can be characterised as breach penalties firms have to pay for breaking employment relationships (see Pita 1997). Hence, the size of the severance payments has to be bargained ex ante. Another possible function of severance payments is the provision function. In this case, the underlying objective is the reduction of financial disadvantages caused by the dismissal. It is therefore clearly future based and ex post negotiations between employers and employees are necessary. ${ }^{3}$ In the sense of such a provision function, severance payments can only be pushed through by legal requirements or with employers having a sense of social responsibility. The latter possibility is usually neglected in economic models. Relevance of this provision function might result in higher severance pay probabilities and sizes for persons faced by unemployment subsequent to their dismissals and individuals with children under age or other obligations to pay maintenance. The empirical relevance of the provision function will be explicitly examined in this study.

The paper proceeds as follows: Section 2 presents the legal framework with respect to severance payments in Germany. Additionally, the results of earlier studies are summarised. Section 3 comprises the empirical study on severance payments for dismissed employees based on the German Socio-Economic Panel. We will respond in detail to the issues, who the beneficiaries of severance payments are, which characteristics determine their levels, and whether overcompensation is important.

\footnotetext{
${ }^{3}$ See Hemmer (1997a: 27-30) for a summary of different possible functions of severance payments.
} 
Individual and collective dismissals are kept separate throughout the study. Section 4 concludes.

\section{Severance pay in Germany - legal framework and prior evidence}

As mentioned above, German law neither lays down general severance payments in the case of individual dismissals nor minimum severance payments in the event of collective dismissals in Germany as opposed to other European countries like France, Spain or the UK. ${ }^{4}$ In spite of the absence of mandatory regulations, severance payments in connection with dismissals can be observed in Germany as well. Different types of severance payments can be distinguished (see e.g. Inhoffen and Müller-Dahl 1981). The first type is based on the Protection Against Dismissal Act ("Kündigungsschutzgesetz"). It is applicable for firms with more than five employees and employees with more than six month of tenure. Severance payments can be the outcome of dismissal protection claims if ordinary dismissals are socially unjustified or extraordinary dismissals are causeless. ${ }^{5}$ In these cases severance payments are arranged if one party makes the application to cancel the employment relationship (although the dismissal was socially not justified), because a further co-operation between the employer and the employee cannot be expected.

A court decision is not necessary for a severance payment. Frequently the parties come to an agreement with the help of a court without an official decision and in many cases

\footnotetext{
${ }^{4}$ See Küchle (1990) and the OECD (1999) for an overview of the legal framework in countries of the European Union.

${ }^{5}$ An ordinary dismissal has to be justified with a misconduct of the employee (e.g. repeated late arrivals), lack of capability (e.g. repeated or long term illness) or redundancies of the firm ( $\$ 1$ Protection Against Dismissal Act). Misconduct of the employees is the reason for the majority of cases (see Falke 1983: 19). See Kittner and Kohler (2000) for a detailed description and discussion of the German legal position in comparison to the USA. Additionally, Emerson (1988: 808-811) and the OECD (1999) provide a summary of international legal frameworks regarding individual and collective dismissals.
} 
employees and employers agree upon a certain amount of severance pay without using a court at all. They may anticipate the costs and the uncertain outcome of claims and are both better off - in terms of expected utility - with a mutual agreement. Additionally, many firms worry about a loss of reputation if conflicts concerning dismissals become public knowledge. ${ }^{6}$ Actually, the share of dismissal protection claims with respect to all dismissals was only about eight percent at the beginning of the 1980s (see Falke 1983: 27). ${ }^{7}$ Unfortunately, it is not possible to get valid data, which are more up to date. However, it is estimated by judges that this fraction has increased in the meantime (see Rüthers 2002: 1603). The number of completed dismissal protection claims in Germany amounts to almost 250,000 in the year 2000.

A different, second type of severance payment can occur in the context of operational changes in connection with mass dismissals and a social plan. ${ }^{8}$ The German Works Constitution Act ("Betriebsverfassungsgesetz”, $\S \S 112-113$ ) defines that a social plan, as a result of the coordination of the interests of the management and the works council, shall allay the economic disadvantages of the dismissed employees, in particular earnings decreases. The German Work Constitution Act aims at firms with at least five employees. A social plan can be conducted with a minimum number of six dismissed employees. ${ }^{9}$ Obviously, the function of a social plan for the firms is somewhat different. From the firms' point of view personnel costs are supposed to be reduced with the help of dismissals and dismissal protection, as well as the necessity of social plans, acts as a restriction of the firms' decision-making authority. Severance payments from dismissal protection claims or settlements can be credited against payments from social plans. Both types of severance payments are paid as a lump sum and not on a weekly or

\footnotetext{
${ }^{6}$ That is why an increasing number of firms authorise some kind of "dismissal consults", who teach managers how to dismiss employees in order to avoid conflicts when dismissals become necessary (see Schrep 2003).

${ }^{7}$ This fraction is somewhat higher, if the dismissals are justified with the behaviour or the person $(0.1)$ than in cases in which the dismissals are justified with operational reasons (0.04).

${ }^{8}$ Heseler and Mückenberger (1999) provide a comprehensive overview of the management of redundancies in Germany.

${ }^{9}$ In detail, a social plan has to be conducted if 20 percent of the workforce or at least six employees are faced (firms with less than 60 employees), 20 percent or at least 37 affected employees (firms with less than 250 employees), 15 percent or at least 60 affected employees (firms with less than 500 employees) and 10 percent or at least 60 affected employees in firms with at least 500 employees.
} 
monthly basis for example. The entitlement to possible unemployment benefits is not affected by the severance pay in general.

The size of severance payments is not clearly determined by law, either. The Protection Against Dismissal Act denominates only maximum limits at the amount of 12 monthly wages in general and 15 or rather 18 monthly wages for older employees with many years of tenure. But there is scope of discretion of the courts, which is endorsed by juridical commentaries on the law, in order to establish an "equitable" severance payment in every single case (see Ascheid et al. 2000: 631ff.). Hence, the size of severance payments should also be determined by future prospects next to past employment characteristics. Apart from court decisions, it is possible that employers and employees make a settlement, which can be coordinated with the help of a judge, though. In this case, an empirical formula, such as a severance payment to an amount of half a monthly wage per year of tenure, is argued to be well established. Characteristics next to tenure and the previous wage that can play a role in court decisions encompass the age ${ }^{10}$, the amount of social adverseness, the economic situation of the firm, the expected or actual unemployment duration of the dismissed employees and maintenance obligations (see Dorndorf at al. 2001: 602-604).

The size of severance payments in the case of collective dismissals using social plans is not fixed either. Some kind of ,severance pay formula“ is usually used to calculate the individual payments for the affected employees. Frequently these payments are increasing with tenure, previous wage and age. But other individual characteristics may be relevant as well. Additionally, the jurisprudence indicates that big companies have to pay more on average because of higher financial opportunities (Inhoffen and MüllerDahl 1981: 1474).

\footnotetext{
${ }^{10}$ Usually, the amount of severance payments should increase with age. But it can also decrease for older employees, who attain mandatory retirement (65 years) in the nearer future.
} 
Only little is known about the size of individual severance payments in Germany up to now. On the basis of a firm sample Falke et al. (1981) find severance payments of DM $7,149^{11}$ on average. But the amounts are very unevenly distributed with few very high payments. The median is about DM 2,700 in this early study. Data of labour courts decisions in Germany at the end of the seventies show that severance payments are arranged at DM 2,000 on average (median) at first instance (see Falke 1983). By dividing the severance payments by monthly wages (in DM) and tenure (in years) it is possible to calculate severance pay factors, which are slightly above 0.5 on average. This means that the labour courts adjudge half a monthly wage per year of tenure to dismissed workers.

In a more recent study, Hemmer (1997a) examines the level of severance payments in the context of social plans. The data contain over 100 firms, which are faced with a social plan. The financial burden of the firms with social plans account for $4 \%$ of personnel expenses or $1.3 \%$ of total revenue in 1995 . The mean severance payment per worker within the social plans of his sample increased from DM 13,360 in 1985 to DM 19,900 in 1995 (see Hemmer 1997a: 113). Hemmer considers possible individual determinants like wages and tenure for the size of severance payments. Unfortunately, he is not able to analyse these features due to lack of data. The relevance of the different possible functions of severance payments has not been examined until now, neither. Remember that higher (probabilities of) severance payments are expected for persons with maintenance obligations and those faced by unemployment subsequent to their dismissal, if a provision function of severance payments is empirically relevant.

\footnotetext{
${ }^{11}$ Within this paper all amounts of severance payments and wages are given in the former currency German Marks (DM). A transformation in Euro can be made by a division by 1.95583 .
} 


\section{Empirical Study}

As it is shown in the previous section, only court decisions and the outcomes of social plans have been analysed in very few studies so far and additionally most of the data are somewhat outdated. Court decisions only account for a small fraction of dismissal protection claims (see Kittner and Kohler 2000: 27). Up to 90 percent of the cases end up with a mutual agreement between the employer and the employee without a court decision. Only 10 percent from the remaining claims result in a success for the employee with an adjudication of a severance payment. Hence, most of the relevant cases of severance payments have not been analysed before. The study presented in this section will use an individual data set from the nineties and integrate all kind of severance payments.

There are hardly any comparable international studies either. To our knowledge, only one study analysed determinants of received severance payments and the amount of severance pay with individual data and multivariate methods so far. Kodrzycki (1998) matches a Massachusetts displaced workers data set with information on severance benefit plans of 15 employers with mass layoffs, which result in some 2,000 observations. She investigates that the probability of receiving a severance payment after a dismissal increases with job tenure, tends to increase with age and is higher in firms of the manufacturing sector. The size of severance pay - measured in the number of weekly wages $^{12}$ - also increased with tenure as well as with former annual earnings, and is below average in the manufacturing sector (see Kodrzycki 1998: 67). The shortcoming of this study is obviously that the data are not representative and only employees of a few firms faced by collective dismissals are taken into account.

\footnotetext{
${ }^{12}$ The form of severance payments varies among employers in Massachusetts. Some are disbursed weekly and others as a lump sum (see Kodrzycki 1998: 44). Hence, the system differs slightly from severance payments in Germany, where generally a lump sum is paid.
} 


\subsection{Data}

This study is based on data from the German Socio-Economic Panel (GSOEP), a yearly representative sample survey of people living in Germany. ${ }^{13}$ The sample of this study is restricted to persons, who were affected by an individual or collective dismissal (including plant closings) within the observation period 1991 to 1998. A distinction between these two kinds of employer-initiated separations is missing in other years of the GSOEP. The sample includes only individuals, who were full-time employees before the dismissal (blue and white collars). Thus, building the data set requires matching information of the individuals of two subsequent years. We have information about the severance payments and the employment status of the present years in addition to the information of the individuals' jobs in the previous year. It yields a sample size of 1,713 dismissed employees, from which 1,098 are affected by an individual and 615 by a collective dismissal. The fraction of the latter group decreases from 40 to $30 \%$ during the observation period. A severance payment is received by 333 (30 percent) individually dismissed employees and 221 (36 percent) collectively dismissed employees (see Table 1 and 2). Hence, two of three dismissed employees in Germany have not received a severance payment until the date of the survey.

This study has got the following objectives: First, the receipt of severance payments is examined. In a second step we analyse the subgroup of employees who received severance payments and ask for the determinants of their size. An integral part is the analysis of the relevance of a provision function of severance payments. Additionally, we have a closer look on the variance of the payments and on the relevance of overcompensation.

\footnotetext{
${ }^{13}$ The data is available from the German Institute of Economic Research (DIW), Berlin.
} 
In order to investigate these issues, we make use of several other variables of the GSOEP as well. At first, there are individual characteristics as sex, age, years of schooling, employment status, citizenship, tenure, marital status and children in the household, for example. Secondly, job based characteristics such as firm size and branch of industry are taken into account as well.

There are only insignificant differences in the descriptive statistics of the persons faced by individual and collective dismissals with respect to most of the variables (see Table 1). Two thirds in the sample are male; nearly half of them have at least one child under age in the household and more than $50 \%$ are blue collar workers. More than $80 \%$ are German, and half of them are from East Germany. Considerable differences can be observed as to the unemployment status at the date of the survey and for years of tenure. Individually dismissed employees are more likely to be unemployed in the next year (0.56 as compared to 0.4 for collective dismissals). ${ }^{14}$ Tenure is much higher for collectively dismissed persons (10.5 years compared to 6.6 years), even though the difference as to the average age is only two years.

\footnotetext{
${ }^{14}$ This difference is not significant based on a T-Test. Hence, it does not fully support the "lemon-story" of Gibbons and Katz (1991). They derive theoretically and find empirical support for the hypothesis that individually dismissed employees have lower productivity and have therefore worse future labour market outcomes in terms of unemployment spells and wages. See Grund (1999) for additional evidence that this stigma effect of layoffs does not hold for Germany to the same extent than in the U.S. or Canada (see in addition Doiron 1995).
} 
Table 1: Descriptive statistics of individual and collective dismissals

\begin{tabular}{|c|c|c|c|c|c|c|}
\hline & \multicolumn{3}{|c|}{ INDIVIDUAL DISMISSALS } & \multicolumn{3}{|c|}{ COLLECTIVE DISMISSALS } \\
\hline & $\begin{array}{c}\text { Whole } \\
\text { sample } \\
(\mathrm{n}=1098)\end{array}$ & $\begin{array}{c}\text { Persons with } \\
\text { severance } \\
\text { payments } \\
(\mathbf{n}=\mathbf{3 3 3}) \\
\end{array}$ & $\begin{array}{c}\text { Persons without } \\
\text { severance } \\
\text { payments } \\
(\mathbf{n}=765) \\
\end{array}$ & $\begin{array}{l}\text { Whole } \\
\text { sample } \\
(n=615)\end{array}$ & $\begin{array}{c}\text { Persons with } \\
\text { severance } \\
\text { payments } \\
(\mathbf{n}=\mathbf{2 2 1}) \\
\end{array}$ & $\begin{array}{c}\text { Persons without } \\
\text { severance } \\
\text { payments } \\
(\mathrm{n}=394)\end{array}$ \\
\hline Severance Payment & 0.303 & 1 & 0 & 0.359 & 1 & 0 \\
\hline Sex (male) & 0.668 & 0.586 & 0.703 & 0.636 & 0.620 & 0.645 \\
\hline Age (years) & 38.7 & 41.51 & 37.48 & 40.88 & 42.55 & 39.94 \\
\hline Years of schooling & 11.22 & 11.53 & 11.08 & 11.62 & 11.54 & 11.66 \\
\hline Marital status (single) & 0.256 & 0.174 & 0.292 & 0.197 & 0.127 & 0.236 \\
\hline Child in household & 0.439 & 0.441 & 0.438 & 0.450 & 0.425 & 0.464 \\
\hline Unemployed at date of survey & 0.562 & 0.562 & 0.556 & 0.399 & 0.407 & 0.335 \\
\hline Blue collar worker & 0.629 & 0.541 & 0.668 & 0.567 & 0.586 & 0.556 \\
\hline Tenure (years) & 6.64 & 11.13 & 4.69 & 10.48 & 14.25 & 8.37 \\
\hline \multicolumn{7}{|l|}{ Firm size: } \\
\hline $1-5$ employees & 0.117 & 0.018 & 0.159 & 0.109 & 0.032 & 0.152 \\
\hline 6 - 19 employees & 0.236 & 0.108 & 0.292 & 0.185 & 0.095 & 0.236 \\
\hline 20 - 199 employees & 0.331 & 0.324 & 0.333 & 0.359 & 0.367 & 0.355 \\
\hline 200 - 1999 employees & 0.208 & 0.366 & 0.139 & 0.228 & 0.326 & 0.173 \\
\hline$\geq 2000$ employees & 0.109 & 0.183 & 0.077 & 0.119 & 0.181 & 0.084 \\
\hline Region (West Germany) & 0.516 & 0.492 & 0.527 & 0.465 & 0.439 & 0.480 \\
\hline Citizenship (German) & 0.801 & 0.817 & 0.793 & 0.847 & 0.842 & 0.850 \\
\hline
\end{tabular}




\subsection{Who receives severance payments?}

As mentioned above, there are no mandatory severance payments in connection with dismissals in Germany and within this sample only one third of the dismissed employees receive a severance payment. Hence, the question arises, whether there are any individual or job based determinants for the receipt of severance payments. A first possibility to analyse this issue is to look at the descriptive statistics of possible determinants, separated for persons with and without severance payments (see Table 1 for individual and collective dismissals separately). Additionally, Table 2 presents the percentages of persons with severance payments in the corresponding subgroups of the sample.

Several variables are inspected for both, the answer of the questions who gets severance payments and which characteristics determine the size of severance payments (subsection 4.3). Tenure, age and the previous wage are mentioned in the Protection Against Dismissal Act and are well known factors of social plan practise as well. Hence, we can expect a positive correlation between these variables and severance payments. Additionally, firm size is obviously important, since the Protection Against Dismissal Act and the works constitution act are not valid for very small firms. Apart from that, the economic situation of the firms regularly influences court decisions (see Dorndorf et al. 2001: 603), which may enlarge severance payments for huge firms, if they have better financial opportunities. If firms account for the individual situation of the dismissed employees, underage children in the household and an actual unemployment status following the dismissal should enlarge the probability and the size of severance payments. Significant effects of these variables would confirm the relevance of a provision function of severance payments as discussed above. There might be also differences between sex, citizenship and occupational status due to some kind of statistical discrimination. If groups of employees differ in the information degree concerning dismissal protection and therefore in the probability to file a suit, firms can try to dismiss the uniformed groups (e.g. foreign employees) without (or with lower) severance 
payments. Last but not least, regional and industry distinctions as well as the year of the dismissal are taken into account.

The univariate results for individual dismissals indicate that a receipt of severance payments is less likely for males, younger employees, singles, employees with less schooling and tenure, blue collars and employees working in small firms. There are significant differences in the means of these variables between the persons with and without severance payments. ${ }^{15}$ The most noticeable differences occur especially as to the firm size. Only 5 percent of dismissed workers in firms with not more than five employees, but more than half in big firms with more than 2,000 employees get severance payments. Additionally, differences between the corresponding percentages of men (0.27) and women (0.38) as well as of singles (0.21) and other marital status (0.34) are remarkably high as well (see Table 2). Table 1 also shows a considerable influence of tenure. The average tenure of persons with severance payment (11.1 years) comes up to more than twice the amount of persons without severance payments (4.7 years). No significant differences can be found as to the citizenship, the region of the workplace, the unemployment status at the date of the survey and the fact that there are children in the household of the dismissed persons.

The results for collective dismissals are similar, but not identical. Again the most striking result is that the probability of severance payments increases with the firm size. The results for sex, blue collars and public service do not differ significantly for collective dismissals. On the other hand, persons who become unemployed after a collective dismissal are more likely to receive a severance payment ( 41 percent) than others (33 percent).

\footnotetext{
${ }^{15}$ This is tested with a usual T-Test on identical averages.
} 
Table 2: Percentage of persons with severance payments in subgroups

\begin{tabular}{lcccc}
\hline & \multicolumn{2}{c}{ Individual dismissals } & \multicolumn{2}{c}{ Collective dismissals } \\
& $\begin{array}{c}\text { Number of } \\
\text { observations }\end{array}$ & $\begin{array}{c}\text { Percentage of } \\
\text { persons with } \\
\text { Severance Pay }\end{array}$ & $\begin{array}{c}\text { Number of } \\
\text { observations }\end{array}$ & $\begin{array}{c}\text { Percentage of } \\
\text { persons with } \\
\text { Severance Pay }\end{array}$ \\
\hline Whole sample & 1098 & 0.303 & 615 & 0.359 \\
Men & 733 & 0.266 & 391 & 0.350 \\
Women & 365 & 0.378 & 224 & 0.375 \\
Single & 281 & 0.206 & 121 & 0.231 \\
Others & 817 & 0.337 & 494 & 0.391 \\
Child in household & 482 & 0.305 & 277 & 0.339 \\
No child in household & 616 & 0.302 & 338 & 0.376 \\
Unemployed at date of survey & 617 & 0.311 & 222 & 0.405 \\
Employed at date of survey & 481 & 0.293 & 393 & 0.333 \\
Blue collars & 691 & 0.260 & 349 & 0.372 \\
White collars & 407 & 0.376 & 266 & 0.342 \\
\multicolumn{1}{c}{ Firm size: } & & & & \\
1 - 5 employees & 128 & 0.047 & 67 & 0.104 \\
6 - 19 employees & 259 & 0.139 & 114 & 0.184 \\
20 - 199 employees & 363 & 0.298 & 221 & 0.367 \\
200 - 1999 employees & 228 & 0.535 & 140 & 0.514 \\
$\geq 2000$ employees & 120 & 0.508 & 73 & 0.548 \\
West Germany & 567 & 0.289 & 286 & 0.339 \\
East Germany & 531 & 0.318 & 329 & 0.377 \\
German & 879 & 0.309 & 521 & 0.357 \\
Foreigner & 219 & 0.279 & 94 & 0.372 \\
\hline
\end{tabular}

Additionally, there might be industry effects that explain differences in receiving severance payments. Table 3 shows that dismissals are more common in the sectors farming, manufacturing and construction. The share of persons in these industries within the sample is much higher than within the whole German workforce. In contrary, dismissals are not so widespread in the service industries. The fraction of persons with severance payments differs considerably between the industries. Especially people who are employed in the industries energy/mining (0.64) and manufacturing (0.43) have high probabilities of severance payments in the case of dismissals. Opposed to that, the fraction is very low for the sectors farming/forestry/fishery and construction (0.17 each). 
Table 3: Severance payments in different industries

\begin{tabular}{|c|c|c|c|}
\hline & $\begin{array}{c}\text { Share of } \\
\text { employees in } \\
\text { the whole } \\
\text { workforce* } \\
\text { (N=27,2 mill.) }\end{array}$ & $\begin{array}{l}\text { Share of } \\
\text { dismissed } \\
\text { persons in } \\
\text { the sample } \\
(n=1713)\end{array}$ & $\begin{array}{l}\text { Fraction of persons } \\
\text { in industry in } \\
\text { sample with } \\
\text { severance payments } \\
(n=554)\end{array}$ \\
\hline Farming, Forestry, Fishery & 0.014 & 0.039 & 0.167 \\
\hline Energy, Mining & 0.016 & 0.021 & 0.639 \\
\hline Manufacturing & 0.297 & 0.392 & 0.433 \\
\hline Construction & 0.075 & 0.176 & 0.173 \\
\hline Retail & 0.137 & 0.138 & 0.258 \\
\hline Transportation, Communication & 0.053 & 0.048 & 0.341 \\
\hline Service industries & 0.309 & 0.144 & 0.248 \\
\hline Regional authorities, Social security & 0.099 & 0.043 & 0.365 \\
\hline$\Sigma$ & 1 & 1 & 0.323 \\
\hline
\end{tabular}

Note: * Employees registered in the German social security system in 1998 (see Statistisches Jahrbuch 1999).

Another possible, and plausible, determinant that influences the probability of receiving severance payments is the general economic situation. Indeed, the correlation between the yearly fraction of dismissed persons, who received severance payments, and the growth rate of the German GDP (0.653) is considerably high during the observation period 1991 to 1998 (see Figure 1 for an illustration and Table $\mathrm{C}$ in the appendix). The correlation is even more obvious for individual dismissals $(0.775)$ than for collective dismissals $(0.414)$. Hence, we observe a higher probability of severance payments in years of high economic growth.

Explanations for this finding are speculative. From an economic point of view, firms could be forced by (the anticipation of) court decisions, who may take the firms' economic situation into account, when judges decide on severance payments in dismissal protection claims. Hereby, the firms' economic situation is highly correlated with the general economic trend. This explanation cannot be separated from possible social motives of firms, whose ability to pay is higher in economically good years. 
Figure 1: Fraction of dismissed persons with severance payments and $\Delta G D P$ in the 1990s

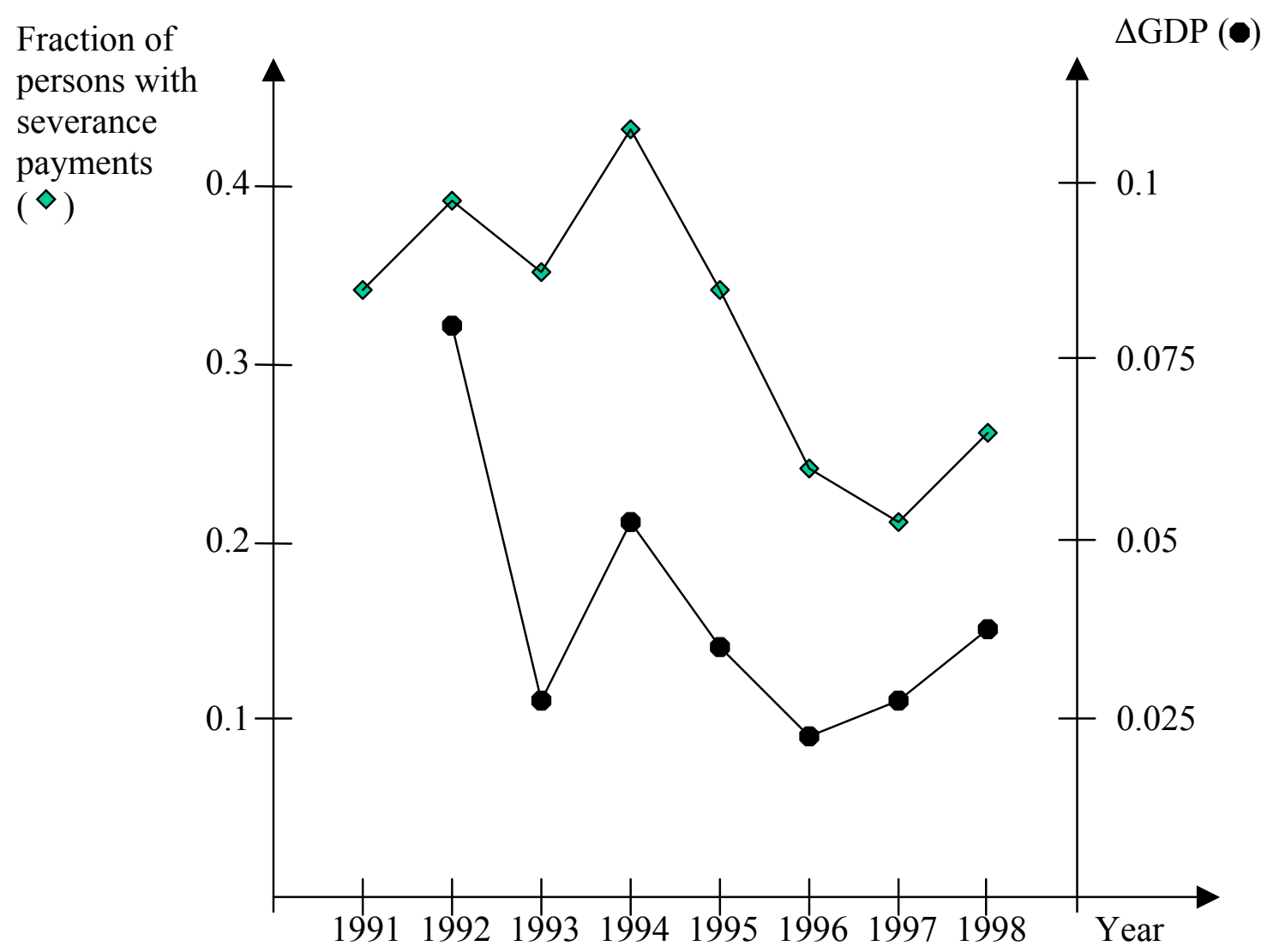

Note: No value for $\Delta$ GDP in 1991 because of the German re-unification in 1990.

But the results up to this point might change, if we use multivariate tools and control for different possible determinants simultaneously. By making use of a binary probit approach we examine the determinants of receiving severance payments. The results are listed in Table 4. The dichotomous dependent variable has got a one in the case of persons with a severance payment and a zero otherwise.

The results confirm that firm size increases the probability of severance payments considerably. Hence, especially small firms with less than six employees, which are not faced by the Protection Against Dismissal Act, do not compensate dismissed persons. 
Unfortunately, it is not possible to control for the existence of works councils in the firms of the dismissed employees. Partly, the firm size effect might rather be a works council's effect, since larger firms are more probable to have a works council and works councils act towards severance payments in negotiations with the management.

Additionally, the probability of severance payments increases with tenure and is significantly higher for women. The positive effect of tenure is in line with anticipated (or actual) court decisions. The longer the relationship endures the more difficult is a dismissal to be socially justifiable. The higher probability of severance payments for women - particularly after individual dismissals - can at least partly be explained by the fact that dismissals caused by misconduct of the employees are more common among males ( 0.67 of all dismissals) compared to females $(0.52$, see Falke $1983: 24)$. It is a reasonable policy for firms to abstain from severance payments for persons dismissed because of misconduct in order to keep the threatening penalty of detected misconduct or shirking as high as possible.

In spite of the very different legal situation for individual and collective dismissals, there are no significant differences with respect to the probability of payments. We can observe considerable differences though between the influencing factors of severance payments with individual and collective dismissals respectively. For individually dismissed persons there are higher probabilities of severance payments for German citizens as compared to foreigners and for West German persons as compared to East Germans. Possibly, employers anticipate that the probability of dismissal protection claims is lower for foreigners, what could make it rational from their point of view to pay severance payments for German rather than for foreign employees. The same explanation may hold for differences between West- and East Germany as well. Since employees (and employers) were not perfectly informed about dismissal protection of employees in the first years after the German re-unification in 1990, risks of dismissal protection claims might have been much lower in East Germany. 
Age, years of schooling, marital status, children in the household and unemployment status at the date of the survey ( 0.5 to 1.5 years after the dismissal) do not affect the severance pay probability significantly. Hence, neither the future job nor individual social criteria are important determinants of receiving severance pay. Apparently the employers do not care very much about the individual situations and future career opportunities of the dismissed employees. There hardly seems to be any relevance of a provision function of severance payments as mentioned in the introduction above.

The results for the industry and year dummies are not listed. In principal the descriptive results are confirmed. The probability of severance payments differs across years cyclically and is particularly high for employees of the energy, mining and manufacturing sector and very low in the farming and construction sector. Possibly, differences between the power of the unions of the single industries are responsible for this result. There is information for individual union membership in the GSOEP in the years 1993 and 1998. Including a union membership dummy in the regression for the sub sample of these years, no effect can be found. But it may also be the case that powerful unions cause higher severance probabilities in these industries for both members and non-members. The evidence is at least in line with this consideration. The net union density ${ }^{16}$, defined as employed union members divided by all employees, is particularly high in the industries with a high fraction of severance payments. For example, the union density of the early 1990s amounts to 0.39 in chemistry, 0.43 in mining and even more in some sub-sectors of manufacturing compared to only 0.17 in the construction sector (see Fitzenberger et al. 1999: 258f).

\footnotetext{
${ }^{16}$ Sometimes a gross union density, defined as all union members over all employees is mentioned as well. Since there are several non-employed union members like students, unemployed and retired persons, this measure overestimates the influence of the unions especially for shrinking industries like mining. Here, the gross union density amounts to 0.7 .
} 
Table 4: Binary probit regressions on received severance payments

\begin{tabular}{|c|c|c|c|}
\hline & $\begin{array}{c}\text { Whole } \\
\text { Sample } \\
\end{array}$ & $\begin{array}{l}\text { Individual } \\
\text { Dismissals }\end{array}$ & $\begin{array}{l}\text { Collective } \\
\text { Dismissals }\end{array}$ \\
\hline Sex (male) & $\begin{array}{c}-0.289 * * * \\
(3.543)\end{array}$ & $\begin{array}{c}-0.308 * * * \\
(2.933)\end{array}$ & $\begin{array}{c}-0.204 \\
(1.474)\end{array}$ \\
\hline Age & $\begin{array}{c}0.001 \\
(0.304)\end{array}$ & $\begin{array}{c}0.006 \\
(1.014)\end{array}$ & $\begin{array}{l}-0.005 \\
(0.623)\end{array}$ \\
\hline Years of Schooling & $\begin{array}{c}0.030 \\
(1.591)\end{array}$ & $\begin{array}{c}0.035 \\
(1.420)\end{array}$ & $\begin{array}{c}0.023 \\
(0.720)\end{array}$ \\
\hline Marital status (single) & $\begin{array}{l}-0.097 \\
(0.826)\end{array}$ & $\begin{array}{c}0.005 \\
(0.030)\end{array}$ & $\begin{array}{l}-0.222 \\
(1.131)\end{array}$ \\
\hline Child in household & $\begin{array}{c}0.091 \\
(1.083)\end{array}$ & $\begin{array}{c}0.174 \\
(1.588)\end{array}$ & $\begin{array}{l}-0.016 \\
(0.116)\end{array}$ \\
\hline Unemployed & $\begin{array}{c}0.003 \\
(0.047)\end{array}$ & $\begin{array}{l}-0.093 \\
(0.972)\end{array}$ & $\begin{array}{c}0.190 \\
(1.517)\end{array}$ \\
\hline Blue collar worker & $\begin{array}{c}0.001 \\
(0.012)\end{array}$ & $\begin{array}{l}-0.140 \\
(1.163)\end{array}$ & $\begin{array}{c}0.219 \\
(1.442)\end{array}$ \\
\hline Tenure & $\begin{array}{c}0.039 * * * \\
(8.555)\end{array}$ & $\begin{array}{c}0.044 * * * \\
(7.126)\end{array}$ & $\begin{array}{c}0.035 * * * \\
(4.686)\end{array}$ \\
\hline \multicolumn{4}{|l|}{ Firm size: } \\
\hline 1 - 5 employees & $\begin{array}{c}-1.094 * * * \\
(6.465)\end{array}$ & $\begin{array}{c}-1.217 * * * \\
(5.233)\end{array}$ & $\begin{array}{c}-0.956 * * * \\
(3.664)\end{array}$ \\
\hline 6 - 19 employees & $\begin{array}{c}-0.442 * * * \\
(4.301)\end{array}$ & $\begin{array}{c}-0.553^{* * *} \\
(4.184)\end{array}$ & $\begin{array}{c}-0.334^{*} \\
(1.901)\end{array}$ \\
\hline 20 - 199 employees & - & - & - \\
\hline 200 - 1999 employees & $\begin{array}{c}0.347 * * * \\
(3.786)\end{array}$ & $\begin{array}{c}0.439 * * * \\
(3.660)\end{array}$ & $\begin{array}{c}0.172 \\
(1.144)\end{array}$ \\
\hline$\geq 2000$ employees & $\begin{array}{c}0.313 * * * \\
(2.743)\end{array}$ & $\begin{array}{l}0.255^{*} \\
(1.712)\end{array}$ & $\begin{array}{c}0.429 * * \\
(2.264)\end{array}$ \\
\hline Region (West Germany) & $\begin{array}{c}0.070 \\
(0.794)\end{array}$ & $\begin{array}{c}0.179 \\
(1.552)\end{array}$ & $\begin{array}{l}-0.036 \\
(0.245)\end{array}$ \\
\hline Citizenship (German) & $\begin{array}{l}0.231 * * \\
(2.047)\end{array}$ & $\begin{array}{c}0.286^{* *} \\
(2.026)\end{array}$ & $\begin{array}{c}0.177 \\
(0.904)\end{array}$ \\
\hline Collective Dismissal & $\begin{array}{l}-0.093 \\
(1.226)\end{array}$ & - & - \\
\hline Intercept & $\begin{array}{c}-1.456^{* * * *} \\
(3.426)\end{array}$ & $\begin{array}{c}-2.200^{* * *} \\
(4.023)\end{array}$ & $\begin{array}{l}-0.690 \\
(0.932)\end{array}$ \\
\hline Industry Dummies & yes & yes & yes \\
\hline Year Dummies & yes & yes & yes \\
\hline Observations & 1713 & 1098 & 615 \\
\hline Log-Likelihood & -860.03 & -509.27 & -326.80 \\
\hline Pseudo $\mathrm{R}^{2}$ & 0.202 & 0.244 & 0.186 \\
\hline
\end{tabular}

Notes: Absolute t-statistics in parentheses.

$*, * *$ and $* * *$ indicate significance at the $0.10,0.05$ and 0.01 level. 
So far we have pointed out the important determinants for the receipt of severance payments. The probability of severance payments depends on both individual characteristics, like in particular tenure but also sex and citizenship, and firm characteristics, like firm size and industry. But nothing is said about the size of severance payments until now. This might differ between different groups of employees as well, which would have important monetary consequences for the affected employees as well as for the economic situations of the firms. Thus, in the next section we analyse the subgroup of dismissed persons with severance payments in more detail. We want to examine the determinants of the size of severance payments. It seems interesting whether high probabilities of severance payments come along with high sizes or, in contrary, whether probability and size act as substitutes.

\subsection{By which characteristics is the size of severance payments determined?}

As already mentioned above, there are some obvious determinants for the size of severance payments. Very often tenure and the wage are used to determine severance payments. But other characteristics might be important as well. For example higher severance payments for persons with children in the household or faced by unemployment may hint to a relevance of a provision function of employers with social motives. Higher payments from big companies may occur due to higher ability to pay.

Tables 5 and 6 indicate that the size of severance payments is higher for men, persons with no child in the household, white collars, persons employed in big firms, and in West Germany. But we can observe higher former wages and partly higher tenure for these groups, too. Therefore, it is useful to calculate so called severance pay factors (see Hemmer 1997a: 146), which are defined by:

$$
\text { Severance pay factor }=\frac{\text { Severance payment }(\text { in DM })}{\text { Gross monthly wage }(\text { in DM }) \cdot \text { Tenure }(\text { in years })} \text {. }
$$


Hence, a severance pay factor of 0.5 means a severance payment of half a monthly wage per year of tenure. Looking at the mean severance pay factors of the variables, we find a different picture compared to the basic size of severance payments. Indeed, there are higher severance pay factors for white collars and in West Germany. These results can be explained with the worse economic situation of East-German firms and with a better relationship of white collared employees to the management respectively. There are no considerable differences for the other variables.

Table 5: Average amount of severance pay in subgroups (individual dismissals)

\begin{tabular}{|c|c|c|c|}
\hline & $\begin{array}{l}\text { Number / share } \\
\text { of observations }\end{array}$ & $\begin{array}{c}\text { Average } \\
\text { amount of } \\
\text { severance pay }\end{array}$ & $\begin{array}{c}\text { Average } \\
\text { severance pay } \\
\text { factor }\end{array}$ \\
\hline Whole sample & 333 & 14081 & 0.494 \\
\hline Men & 0.59 & 17204 & 0.497 \\
\hline Women & 0.41 & 9669 & 0.491 \\
\hline Single & 0.17 & 8522 & 0.612 \\
\hline Other marital status & 0.83 & 15254 & 0.470 \\
\hline Child in household & 0.44 & 13420 & 0.477 \\
\hline No child in household & 0.56 & 14604 & 0.516 \\
\hline Unemployed at date of survey & 0.58 & 15477 & 0.470 \\
\hline Employed at date of survey & 0.42 & 12181 & 0.528 \\
\hline Blue collars & 0.54 & 11217 & 0.394 \\
\hline White collars & 0.46 & 17451 & 0.612 \\
\hline \multicolumn{4}{|l|}{ Firm size: } \\
\hline 1 - 5 employees & 0.02 & 6583 & 0.209 \\
\hline 6 - 19 employees & 0.11 & 7954 & 0.373 \\
\hline 20 - 199 employees & 0.32 & 9652 & 0.489 \\
\hline 200 - 1999 employees & 0.37 & 16008 & 0.454 \\
\hline$\geq 2000$ employees & 0.18 & 22424 & 0.886 \\
\hline West Germany & 0.49 & 17672 & 0.590 \\
\hline East Germany & 0.51 & 10597 & 0.402 \\
\hline German & 0.82 & 13962 & 0.498 \\
\hline Foreigner & 0.18 & 14615 & 0.479 \\
\hline
\end{tabular}

Note: Severance pay factor $=$ amount of severance pay / (gross monthly wage $*$ tenure). 
Whereas the average amount of severance pay is higher for persons faced by collective dismissals (DM 17,000) compared with individual dismissals (DM 14,000), things change as to the average severance pay factor, which is higher for individual dismissals $(0.49$ versus $0.42)$.

Table 6: Average amount of severance pay in subgroups (collective dismissals)

\begin{tabular}{lccc}
\hline & $\begin{array}{c}\text { Number/share } \\
\text { of observations }\end{array}$ & $\begin{array}{c}\text { Average } \\
\text { amount of } \\
\text { severance pay }\end{array}$ & $\begin{array}{c}\text { Average } \\
\text { severance pay } \\
\text { factor }\end{array}$ \\
\hline Whole sample & 221 & 17016 & 0.417 \\
Men & 0.62 & 20471 & 0.395 \\
Women & 0.38 & 11381 & 0.454 \\
Single & 0.13 & 14072 & 0.381 \\
Other marital status & 0.87 & 17443 & 0.423 \\
Child in household & 0.43 & 13924 & 0.443 \\
No child in household & 0.57 & 19304 & 0.398 \\
Unemployed at date of survey & 0.41 & 20994 & 0.387 \\
Employed at date of survey & 0.59 & 14283 & 0.438 \\
Blue collars & 0.59 & 13284 & 0.360 \\
White collars & 0.41 & 22347 & 0.500 \\
& & & \\
1 - 5 employees & 0.03 & 14424 & 0.308 \\
6 - 19 employees & 0.10 & 10662 & 0.466 \\
20 - 199 employees & 0.37 & 11471 & 0.371 \\
200 - 1999 employees & 0.33 & 22805 & 0.407 \\
$\geq 2000$ employees & 0.18 & 21486 & 0.523 \\
West Germany & 0.44 & 25909 & 0.540 \\
East Germany & 0.56 & 10059 & 0.321 \\
German & 0.84 & 17283 & 0.396 \\
Foreigner & 0.16 & 15596 & 0.533 \\
\hline Not: Severance & & & \\
\hline
\end{tabular}

Note: Severance pay factor $=$ amount of severance pay / (gross monthly wage $*$ tenure).

Next to the comparison of the averages, the analysis of the distribution of severance payments is useful. We can observe a huge variance as to the amount of severance payments as well as to the severance pay factor (see Figure 2 and 3 as well as Table D in the appendix). 20 percent of severance payments do not exceed 3,000 DM. However, 10 percent of severance payments in the sample come at least to DM 30,000 in the case of individual dismissals and even DM 
44,000 in the case of collective dismissals. This huge span is not only caused by individual differences in the previous wage and/or tenure.

Figure 2: Distribution of severance payments

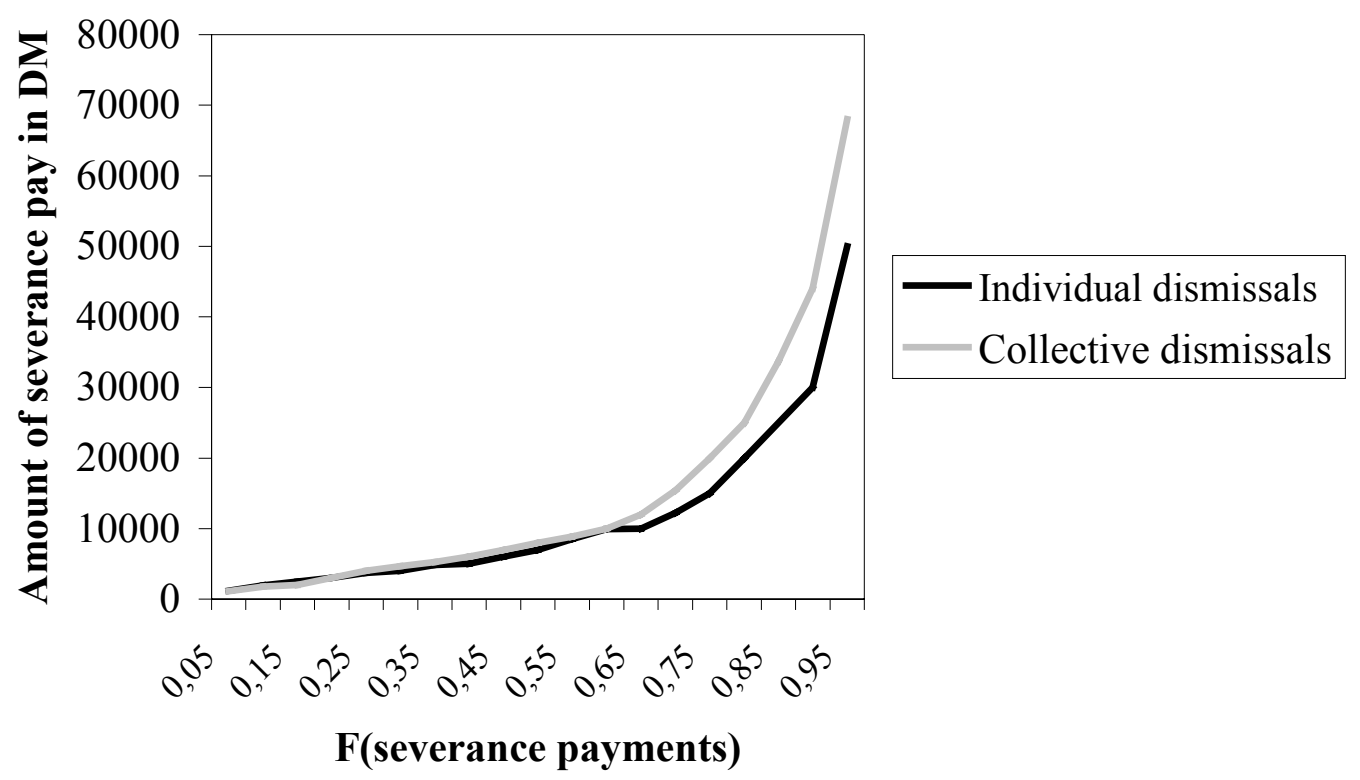

Figure 3: Distribution of severance pay factors

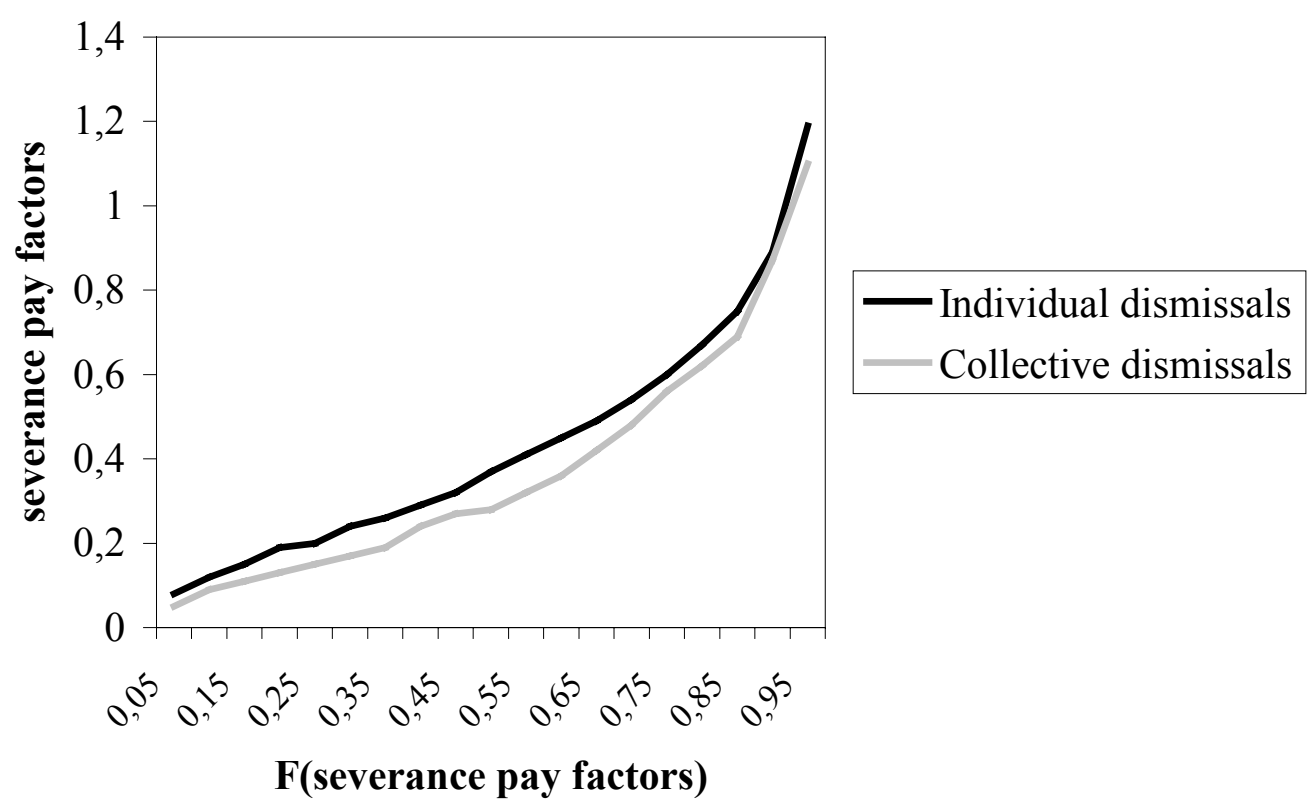

Note: $F(\cdot)=$ Distribution function of severance payments (figure 2 ) respectively severance pay factors (figure 3). 
The distribution of the severance pay factors reveals considerable inequality as well. 10 percent of the individually dismissed persons receive a factor of at least 0.89 , whereas the bottom $10 \%$ of the distribution has to be content with a factor of at most 0.12 . Over the whole distribution the severance pay factor is slightly lower for collective dismissals. The corresponding values for the $10^{\text {th }}$ and the $90^{\text {th }}$ percentile are 0.09 and 0.87 respectively.

Despite the observed huge variance in the data, there are some significant determinants of the amount of severance pay, what is shown by regressions. The full set of variables like in subsection 5.2 is used in addition to the gross monthly wage in the previous job within a simple OLS approach to explain the log of the amount of severance payments (see Table 7). Making use of the same variables again, a comparison to the results of subsection 3.2 is possible. It turns out that tenure, wage in the previous job, age, sex, region and firm size are the significant factors within this specification. The other variables, as well as the year and industry dummies, have no significant effect. Although the coefficients for unemployment status and children under age in the household have positive signs, a significant "social bonus" for these groups of individuals cannot be confirmed. Hence, we cannot find clear empirical evidence for a provision function of severance payments.

The most important determinant for severance payments is the wage in the previous job. The average wage in the sample is DM 3,263. Hence, the coefficient of 0.0003 means that on average a doubling of the wage doubles the severance payment as well. One additional year of tenure raises severance payments to an amount of 5 percent and an additional year of age to 1.5 percent. Taking into account the average tenure (12.4 years) and age (42 years) of the persons in the sample, it can be shown that a doubling of tenure or age means somewhat less than a doubling of severance payments on average.

Additionally, the amount of severance payments increases with the size of the firm. The received payments of employees from big firms with more than 2000 employees are 50 percent higher than in medium sized firms with 20 to 200 employees. This is particularly true for individual dismissals. The results for sex and region differ considerably between the estimations for individual and collective dismissals as well. Significant differences between men and women as well as West- and East Germany cannot be observed in the case of individual dismissals. However, severance payments in the context of collective dismissals 
are a quarter lower for men as compared to women and almost twice as high in West Germany as compared to East Germany. Subsequent to the German re-unification many EastGerman firms were bankrupt and did not have the financial opportunities to afford higher severance payments even if they would have wanted to. Gender differences might be explained by a possible attempt of the firms to adjust lower reemployment probabilities of women. In the sample nearly one half of the male employees is reemployed in the subsequent year, but only one third of female workers.

Recapitulating, the average severance payment in the 1990s in Germany amounts to 15,000 German Marks. However, a huge variance can be observed, which can still be found, when we look at severance pay factors defined as the individual severance payment divided by the previous gross monthly wage and tenure. In fact, the previous wage and tenure are the most important determinants of the size of severance payments. But age, firm size, region and sex are relevant factors as well.

In order to discuss the effects of severance payments for the individuals, the reemployment rates have already been mentioned. If an employee, who received a severance payment, finds a job immediately after her dismissal and possibly even increases her wage, she is better off compared to a further employment in her previous firm. This leads directly to the question of the relevance of overcompensation. 
Table 7: OLS-Repressions on the amount of severance payments

\begin{tabular}{|c|c|c|c|}
\hline & $\begin{array}{c}\text { Whole } \\
\text { Sample }\end{array}$ & $\begin{array}{l}\text { Individual } \\
\text { Dismissals }\end{array}$ & $\begin{array}{l}\text { Collective } \\
\text { Dismissals }\end{array}$ \\
\hline Sex (male) & $\begin{array}{c}-0.184 * * \\
(2.236)\end{array}$ & $\begin{array}{c}-0.088 \\
(0.927)\end{array}$ & $\begin{array}{c}-0.295^{*} \\
(1.824)\end{array}$ \\
\hline Age & $\begin{array}{c}0.015 * * * \\
(3.063)\end{array}$ & $\begin{array}{c}0.019 * * * \\
(3.066)\end{array}$ & $\begin{array}{c}0.012 \\
(1.314)\end{array}$ \\
\hline Years of Schooling & $\begin{array}{l}-0.009 \\
(0.477)\end{array}$ & $\begin{array}{l}-0.024 \\
(1.070)\end{array}$ & $\begin{array}{c}0.011 \\
(0.295)\end{array}$ \\
\hline Marital status (single) & $\begin{array}{l}-0.103 \\
(0.838)\end{array}$ & $\begin{array}{l}-0.008 \\
(0.052)\end{array}$ & $\begin{array}{l}-0.204 \\
(0.891)\end{array}$ \\
\hline Child in household & $\begin{array}{c}0.111 \\
(1.319)\end{array}$ & $\begin{array}{l}0.181^{*} \\
(1.769)\end{array}$ & $\begin{array}{c}0.060 \\
(0.395)\end{array}$ \\
\hline Unemployed at date of survey & $\begin{array}{c}0.024 \\
(0.315)\end{array}$ & $\begin{array}{c}0.116 \\
(1.302)\end{array}$ & $\begin{array}{l}-0.085 \\
(0.602)\end{array}$ \\
\hline Blue collar worker & $\begin{array}{c}-0.096 \\
(1.063)\end{array}$ & $\begin{array}{c}-0.135 \\
(1.271)\end{array}$ & $\begin{array}{c}-0.118 \\
(0.690)\end{array}$ \\
\hline Tenure & $\begin{array}{c}0.048^{* * *} \\
(10.54)\end{array}$ & $\begin{array}{c}0.045^{* * * *} \\
(8.437)\end{array}$ & $\begin{array}{c}0.052 * * * \\
(5.916)\end{array}$ \\
\hline Monthly Gross Wage & $\begin{array}{c}0.0003 * * * \\
(10.17)\end{array}$ & $\begin{array}{c}0.0003 * * * \\
(8.929)\end{array}$ & $\begin{array}{c}0.0003 * * * \\
(4.895)\end{array}$ \\
\hline 1 - 5 employees & $\begin{array}{l}-0.258 \\
(1.086)\end{array}$ & $\begin{array}{l}-0.283 \\
(0.865)\end{array}$ & $\begin{array}{l}-0.164 \\
(0.441)\end{array}$ \\
\hline 6 - 19 employees & $\begin{array}{l}-0.026 \\
(0.217)\end{array}$ & $\begin{array}{l}-0.181 \\
(1.227)\end{array}$ & $\begin{array}{c}0.212 \\
(0.917)\end{array}$ \\
\hline 20 - 199 employees & - & - & - \\
\hline 200 - 1999 employees & $\begin{array}{c}0.208^{* *} \\
(2.480)\end{array}$ & $\begin{array}{l}0.176^{*} \\
(1.777)\end{array}$ & $\begin{array}{l}0.272 * \\
(1.767)\end{array}$ \\
\hline$\geq 2000$ employees & $\begin{array}{c}0.436 * * * \\
(4,259)\end{array}$ & $\begin{array}{c}0.509 * * * \\
(4.176)\end{array}$ & $\begin{array}{c}0.307 \\
(1.626)\end{array}$ \\
\hline Region (West Germany) & $\begin{array}{c}0.289 * * * \\
(2.770)\end{array}$ & $\begin{array}{c}0.089 \\
(0.730)\end{array}$ & $\begin{array}{c}0.646^{* * *} \\
(3.118)\end{array}$ \\
\hline Citizenship (German) & $\begin{array}{c}-0.024 \\
(0.207)\end{array}$ & $\begin{array}{l}-0.099 \\
(0.728)\end{array}$ & $\begin{array}{c}0.174 \\
(0.781)\end{array}$ \\
\hline Collective dismissal & $\begin{array}{c}0.023 \\
(0.327)\end{array}$ & - & - \\
\hline Intercept & $\begin{array}{c}6.986 * * * \\
(15.75)\end{array}$ & $\begin{array}{c}6.763 * * * \\
(12.19)\end{array}$ & $\begin{array}{c}6.917 * * * \\
(8.731)\end{array}$ \\
\hline Industry dummies & yes & yes & yes \\
\hline Year dummies & yes & yes & yes \\
\hline Observations & 554 & 332 & 221 \\
\hline $\mathrm{R}_{\text {adj. }}^{2}$ & 0.565 & 0.601 & 0.515 \\
\hline
\end{tabular}

Notes: Absolute t-statistics in parentheses.

$*, * *$ and $* * *$ indicate significance at the $0.10,0.05$ and 0.01 level. 


\subsection{Is overcompensation to be considered a relevant issue?}

In order to answer this question it is first of all necessary to define and create a measure for overcompensation. One can speak of an overcompensated dismissed employee, if the present value of future wages in addition to the severance payment exceeds the hypothetical present value of the wage profile in the dismissing firm (see e.g. Fabel 1996). This definition cannot be used with the data of the GSOEP. Therefore, we will speak of overcompensation, if a person received a severance payment and has a higher wage in her new job after the dismissal. Certainly, this simple measure is imperfect, because on the one hand overcompensation may also occur in cases with high severance payments and minor wage reductions or moderate durations of unemployment. ${ }^{17}$ On the other hand, wage increases may be transitory. But because of the relevance of increasing wage profiles the latter argument does probably not fit for many cases. Hence, the applied proxy for overcompensation might be interpreted as a lower bound for actual overcompensation.

Indeed, a substantial fraction can be assigned to the category of overcompensated employees even with this definition. Almost one fourth of dismissed persons with severance payments are reemployed and experience a wage increase (see Table 8). Based on the fraction of reemployed persons, even more than half get a higher wage in addition to the severance payment.

\footnotetext{
${ }^{17}$ Unemployed persons receive unemployment benefits amounting to 60 percent of their net monthly wage of the last year, if they have been employed subject to social insurance contribution at least 12 months within the last three years. This fraction increases to 0.67 if the person has at least one child. The duration of the claim depending on the duration of previous employment and the age - is between 6 and 32 months. Additionally, a reduced tax rate for severance payments can enlarge the relevance of overcompensation.
} 
Table 8: Consequences of dismissals - reemployment rates and wage increases

\begin{tabular}{lccc}
\hline & $\begin{array}{c}\text { Whole } \\
\text { sample }\end{array}$ & $\begin{array}{c}\text { Individual } \\
\text { dismissals }\end{array}$ & $\begin{array}{c}\text { Collective } \\
\text { dismissals }\end{array}$ \\
\hline Number of observations (n) & 1713 & 1098 & 615 \\
Reemployed persons (share of n) & 0.448 & 0.377 & 0.576 \\
Persons with wage increases (share of n) & 0.246 & 0.195 & 0.338 \\
& & & \\
Persons with severance payments (sp) & 554 & 333 & 221 \\
Reemployed persons (share of sp) & 0.428 & 0.366 & 0.520 \\
Persons with wage increases (share of sp) & 0.238 & 0.192 & 0.308 \\
\hline
\end{tabular}

Persons with severance payments are not worse off in their subsequent careers compared to dismissed employees without severance payments. Hence, once again a particular relevance of a provision function of severance payments cannot be confirmed.

The reemployment rate is much higher in cases of collective dismissals. While more than 50 percent of the affected persons are reemployed in the next year, only slightly more than one third of individually dismissed employees have a new job. However, the distribution of wage increases within the subgroup of reemployed persons with or without severance payments is very similar between individual and collective dismissals.

To sum up, we can state that overcompensation is indeed a relevant phenomenon. Although in many cases severance payments are required to finance times of non-employment, a lot of persons are better off with their severance pay in addition to higher wages.

Finally, some hints due to shortcomings of the data have to be given. First, a legally required period of notice is usually part of the employment contract after a common six-month probation period. This period of notice starts with one month and is increasing with tenure up to seven months for employees with tenure of more than 20 years. Sometimes dismissed employees do not have to work the whole remaining time, but do get their wage until the expiration of the contract. Hence, this continued pay after dismissals without duty to work corresponds to severance payments. Additionally, not every court decision may have been made by the time of the survey of the GSOEP. Although 80 percent of dismissal protection 
claims are finished within six months and almost all after twelve months (see Franke 1996: 100), some dismissal protection claims were probably not concluded at the date of the particular survey. ${ }^{18}$ In sum, slightly more than one third of dismissed employees may benefit from severance payments and the size of the payments may be slightly underestimated as well. For a more detailed analysis it would be helpful to have additional information on the reason of each dismissal and on whether the employees took legal action.

\section{Conclusion}

In this empirical study we analysed severance payments for dismissed employees in Germany in the 1990s. In particular we responded to the questions: 1.) "Who gets severance payments?"“ 2.) "How much do recipients get?"“ and 3.) "Is overcompensation relevant?"“ It turned out that approximately one third of dismissed employees receive a severance payment from their former employers. Tenure and firm size are the most important determinants with respect to the receipt of a severance bonus. Additionally there are industry and business cycle effects, though. The size of severance payments is slightly higher for collectively (DM 17,000) than individually dismissed persons (DM 14,000). The most important determinants for the size are tenure and the previous wage. However, age, firm size and regional effects do matter as well. About one quarter of dismissed employees are better off in the future in the sense that they receive higher wages in addition to a severance bonus. Although a provision function of severance payments is laid down by law in Germany, there is not much evidence for adequate empirical relevance.

The huge variances in the results are worth mentioning. Hence, there is enormous uncertainty for both, employees and employers about the bonuses or respectively the costs of dismissals at least since severance payments are not fixed in an ex ante bargaining. Due to the unspecified legal situation it seems to be beneficial for employees to insist on severance

\footnotetext{
${ }^{18}$ Note that the survey is conducted at the mid of each year and the individuals provide information about the whole last calendar year.
} 
payments and threaten with a suit in order to increase the chance of a substantial severance payment. ${ }^{19}$ Taking this behaviour into account, employers might be better off by fixing a (generous) amount of severance payment as an explicit part of the employment contract. This might even reduce total wage costs, because risk premiums of risk averse employees can be economised.

Focussing on collective dismissals it is stated by Hemmer (1997c: 130) that two of three firms wish the legal framework of social plans to be improved. Apart from that, Hemmer (1997b: 102) points out that firms more and more often make use of alternative procedures of the adaptation of staffing levels instead of dismissals, such as early retirement plans, training programs, assistance to become self-employed, outplacement and so on.

There is much discussion about modifications of the German severance pay system. Some authors propose a more explicit orientation of the size of severance payments on the economic situation of the dismissed employees, which is in line with the German Work Constitution Act (§112). In detail, Hemmer (1997c: 132f) suggests that the severance payment should increase with future employment status. This might be an improvement in terms of equity, but neglects harmful incentives for omitted job search.

An increasing number of politicians as well as researchers discuss the possibility of introducing mandatory severance payments for dismissed employees in Germany for macroeconomic reasons as well (see e.g. IZA 2002, Jahn 2002, Handelsblatt 2003). It is often argued that the uncertain legal situation leads to a reduction of recruitments. Concrete suggestions include an annulment of dismissal protection within the first years of tenure in favour of a mandatory severance pay of e.g. one monthly wage per year of tenure. On principle, such a kind of modification of the legal situation concerning severance payments seems to be reasonable.

\footnotetext{
${ }^{19}$ This is an integral part of the theoretic model of Galdon-Sanchez and Güell (2003) as well.
} 


\section{References}

Addison, J.; J. Grosso (1996): Job Security Provisions and Employment: Revised Estimates. In: Industrial Relations (35), 585-603.

Addison, J; P. Teixeira; J. Grosso (2000): The Effects of Dismissals Protection on Employment: More on a Vexed Theme. In: Southern Economic Journal (67), 105-122.

Bertola, G. (1990): Job Security, Employment, and Wages. In: European Economic Review (34), 851-886.

Blanchard, O.; J. Wolfers (2000): The Role of Shocks and Institutions in the Rise of European Unemployment: The Aggregate Evidence. In: The Economic Journal (110), C1-C33.

Boeri (1999): Enforcement of Employment Security Regulations, On-the-Job Search and Unemployment Duration. In: European Economic Review (43), 65-89.

Booth, A. L. (1994): Layoffs with Payoffs: A Bargaining Model of Union Wage and Severance Pay Determination. In: Economica (62), 551-564.

Burda, M. (1991): Monopolistic Competition, Costs of Adjustment, and the Behavior of European Manufacturing Employment. In: European Economic Review (35), 61-79.

Burda, M. (1992): A Note on Firing Costs and Severance Benefits in Equilibrium Unemployment. In: Scandinavian Journal of Economics (94), 479-489.

Del Boca, A.; P. Rota (1998): How Much Does Hiring and Firing Cost? Survey Evidence from a Sample of Italian Firms. In: Labour (12), 427-449.

Doiron, D. J. (1995): Lay-offs As Signals: The Canadian Evidence. Canadian Journal of Economics 28 (1995), 899-913.

Dorndorf, E. et al. (2001): Heidelberger Kommentar zum Kündigungsschutzgesetz, 4. Auflage, Heidelberg.

Emerson, Michael (1988): Regulation or Deregulation of the Labour Market. In: European Economic Review (32), 775-817.

Fabel, O. (1996): Abfindungszahlungen an entlassene Arbeitnehmer. In: Zeitschrift für Betriebswirtschaft (66), 587-606.

Fabel, O. (2002): Severance Pay Rules and Structural Layoff Decisions. In: Schmalenbach Business Review (54 of zfbf), 118-135.

Falke, J. (1983): Kündigungspraxis und Kündigungsschutz. In: Ellermann-Witt et al. (eds.): Beiträge zur sozialwissenschaftlichen Forschung, Opladen, 13-43.

Falke, J. et al. (1981): Kündigungspraxis und Kündigungsschutz in der Bundesrepublik Deutschland, Reihe „Forschungsberichte“ hrsg. vom Bundesminister für Arbeit und Sozialordnung, Bonn.

Financial Times Deutschland (2000): Mannesmann/Vodafone: Esser bekommt 60,5 Mio. DM Abfindung (11.2.2000, URL: http://www.ftd.de/tm/tk/1047263.html)

Fitzenberger, B.; I. Haggeney; M. Ernst (1999): Wer ist noch Mitglied in Gewerkschaften eine Paneldatenanalyse für Westdeutschland. Zeitschrift für Wirtschafts- und Sozialwissenschaften (119), 223-263.

Franke, K. (1996): Effizienz gesetzlicher Kündigungsschutzbestimmungen. Wiesbaden.

Galdon-Sanchez, J. E. ; M. Güell (2003) : Dismissal Conflicts and Unemployment (47), 323335.

Gibbons, R.; L. F. Katz (1991): Layoffs and Lemons. Journal of Labor Economics (9), 351380.

Goerke, L. (2003): Redundancy Pay and Collective Dismissals. In: FinanzArchiv (59), 68-90.

Grund, C. (1999): Stigma Effects of Layoffs? Evidence from German Micro-Data. Economics Letters (64), 241-247. 
Hamermesh, D.; G. Pfann (1996): Adjustment Costs in Factor Demand. In: Journal of Economic Literature (34), 1264-1292.

Handelsblatt (2003): Schröder will im Bündnis für Arbeit über Tabuthemen reden (21.01.2003), 1 .

Hemmer, E. (1997a): Sozialpläne und Personalanpassungsmaßnahmen - Eine empirische Untersuchung, Köln.

Hemmer, E. (1997b): Kritik der Unternehmen an Sozialplanregelungen. Der Arbeitgeber (49), 102-105.

Hemmer, E. (1997c): Sozialplanregelungen verbessern. In: Der Arbeitgeber (49), 130-135.

Heseler, H.; U. Mückenberger (1999): The Management of Redundancies in Europe: The Case of Germany. In: Labour (13), 183-235.

Hunt, J. (2000): Firing Costs, Employment Fluctuations and Average Employment: An Examination of Germany. In: Economica (67), 177-202.

Inhoffen, A.O.; Müller-Dahl, F.P. (1981): Rückstellungen für Abfindungen aus Sozialplan und Aufhebungsvertrag? In: Der Betrieb (34), 1473-1477.

IZA (2002): Bessere Rahmenbedingungen für mehr Beschäftigung. IZA Compact. Sonderausgabe, November 2002.

Kittner, M.; T.C. Kohler (2000): Kündigungsschutz in Deutschland und den USA. In: Betriebsberater (55), supplement to issue 13/2000.

Kodrzycki, Y. K. (1998): The Effects of Employer-Provided Severance Benefits on Reemployment Outcomes. In: New England Economic Review (November/December 1998), 41-68.

Küchle, H. (1990): Kündigungsschutzvorschriften im internationalen Vergleich. In: WSIMitteilungen, 407-414.

Kugler, A. D. (2002): From Severance Pay to Self-Insurance: Effects of Severance Payments Savings Accounts in Columbia. IZA Discussion Paper, No. 434.

Lazear, E. P. (1990): Job Security and Employment. In: Quarterly Journal of Economics (105), 699-725.

Malo, M. A. (2000): A Simple Model of Severance Pay Determination: The Case of Individual Dismissals in Spain. In: Labour (14), 269-290.

Malo, M. A. (2001): European Labour Law and Severance Pay Determination in Collective Redundancies. In: European Journal of Law and Economics (12), 73-90.

Nickell, S. (1997): Unemployment and Labor Market Rigidities: Europe versus North America. In: Journal of Economic Perspectives (11), 55-74.

Nickell, S.; R. Layard (1999): Labor Market Institutions and Economic Performance. In: Ashenfelter, O.; D. Card (Eds.): Handbook of Labor Economics (Vol. 3c), Amsterdam, New York.

OECD (1999): Employment Outlook, Paris.

Oi, W. (1962): Labor as Quasi-Fixed Factor. In: Journal of Political Economy (70), 538-555.

Pencavel, J. (2001): The Response of Employees to Severance Incentives - The University of California's Faculty, 1991-94. In: The Journal of Human Resources (36), 58-84.

Pita, C. (1997): Breach Penalties in Labour Contracts: Advance Notice and Severance Pay. In: Labour (11), 469-495.

Rüthers, B. (2002): Vom Sinn und Unsinn des geltenden Kündigungsschutzrechts. In: Neue Juristische Wochenschrift (55), 1601-1609.

Schrep, B. (2003): Geräuschlos gefeuert. In: Der Spiegel (2.6.2003), 50-52.

Suedekum, J.; P. Ruehmann (2003): Severance Payments and Firm-specific Human Capital. In. Labour (17), 47-62.

Statistisches Bundesamt (1999): Statistisches Jahrbuch für die Bundesrepublik Deutschland, Wiesbaden. 


\section{Appendix}

Table A: Descriptive statistics of individual dismissals

\begin{tabular}{lccc}
\hline & All & $\begin{array}{c}\text { Persons } \\
\text { with } \\
\text { severance } \\
\text { payments } \\
(\mathbf{n = 3 3 3 )}\end{array}$ & $\begin{array}{c}\text { Persons } \\
\text { without } \\
\text { severance } \\
\text { payments } \\
\text { (n=765) }\end{array}$ \\
\hline Severance Payment & 0.303 & 1 & 0 \\
Sex (male) & 0.668 & 0.586 & 0.703 \\
Age (years) & 38.7 & 41.51 & 37.48 \\
Years of schooling & 11.22 & 11.53 & 11.08 \\
Marital status (single) & 0.256 & 0.174 & 0.292 \\
Child in household & 0.439 & 0.441 & 0.438 \\
Unemployed at date of survey & 0.562 & 0.562 & 0.556 \\
Blue collar worker & 0.629 & 0.541 & 0.668 \\
Tenure (years) & 6.64 & 11.13 & 4.69 \\
$\quad$ Firm size: & & & \\
1 - 5 employees & 0.117 & 0.018 & 0.159 \\
6 - 19 employees & 0.236 & 0.108 & 0.292 \\
20 - 199 employees & 0.331 & 0.324 & 0.333 \\
200 - 1999 employees & 0.208 & 0.366 & 0.139 \\
$\geq 2000$ employees & 0.109 & 0.183 & 0.077 \\
Region (West Germany) & 0.516 & 0.492 & 0.527 \\
Citizenship (German) & 0.801 & 0.817 & 0.793 \\
\hline
\end{tabular}


Table B: Descriptive statistics of collective dismissals

\begin{tabular}{lccc}
\hline & $\begin{array}{c}\text { Whole } \\
\text { sample }\end{array}$ & $\begin{array}{c}\text { Persons } \\
\text { with } \\
\text { severance } \\
\text { payments } \\
\text { (n=221) }\end{array}$ & $\begin{array}{c}\text { Persons } \\
\text { without } \\
\text { severance } \\
\text { payments } \\
\text { (n=394) }\end{array}$ \\
\hline Severance Payment & 0.359 & 1 & 0 \\
Sex (male) & 0.636 & 0.620 & 0.645 \\
Age (years) & 40.88 & 42.55 & 39.94 \\
Years of schooling & 11.62 & 11.54 & 11.66 \\
Marital status (single) & 0.197 & 0.127 & 0.236 \\
Child in household & 0.450 & 0.425 & 0.464 \\
Unemployed at date of survey & 0.399 & 0.407 & 0.335 \\
Blue collar worker & 0.567 & 0.586 & 0.556 \\
Tenure (years) & 10.48 & 14.25 & 8.37 \\
\multicolumn{1}{c}{ Firm size: } & & & 0.152 \\
1 - 5 employees & 0.109 & 0.032 & 0.236 \\
6 - 19 employees & 0.185 & 0.095 & 0.355 \\
20 - 199 employees & 0.359 & 0.367 & 0.173 \\
200 - 1999 employees & 0.228 & 0.326 & 0.084 \\
22000 employees & 0.119 & 0.181 & 0.480 \\
Region (West Germany) & 0.465 & 0.439 & 0.850 \\
Citizenship (German) & 0.847 & 0.842 & \\
\hline
\end{tabular}


Table C: Fraction of dismissed persons with severance payments and $\Delta$ GDP in the 1990s (corresponds to Figure 1)

\begin{tabular}{ccc}
\hline Year & $\begin{array}{c}\text { Fraction of dismissed persons, who } \\
\text { received severance payments }\end{array}$ & $\Delta$ GDP \\
\hline 1991 & 0.343 & $---*$ \\
1992 & 0.386 & 0,079 \\
1993 & 0.351 & 0,028 \\
1994 & 0.433 & 0,052 \\
1995 & 0.341 & 0,034 \\
1996 & 0.239 & 0,023 \\
1997 & 0.215 & 0,028 \\
1998 & 0.255 & 0,037 \\
\hline
\end{tabular}

Note: *: Value for $\Delta$ GDP is missing in 1991 because of the German re-unification in 1990.

Table C: Distribution of severance payments and severance pay factors (corresponds to Figure 2 and 3)

\begin{tabular}{lcccc}
\hline & \multicolumn{2}{c}{ Amount of severance payment } & \multicolumn{2}{c}{ Severance pay factor } \\
Percentile & $\begin{array}{c}\text { Individual } \\
\text { dismissals }\end{array}$ & $\begin{array}{c}\text { Collective } \\
\text { dismissals }\end{array}$ & $\begin{array}{c}\text { Individual } \\
\text { dismissals }\end{array}$ & $\begin{array}{c}\text { Collective } \\
\text { dismissals }\end{array}$ \\
\hline $\mathbf{0 . 1}$ & 1,975 & 1,800 & 0.12 & 0.09 \\
$\mathbf{0 . 2}$ & 3,000 & 3,000 & 0.19 & 0.13 \\
$\mathbf{0 . 3}$ & 4,000 & 4,650 & 0.24 & 0.17 \\
$\mathbf{0 . 4}$ & 5,000 & 6,000 & 0.29 & 0.24 \\
$\mathbf{0 . 5}$ & 7,000 & 8,000 & 0.37 & 0.28 \\
$\mathbf{0 . 6}$ & 9,900 & 10,000 & 0.45 & 0.36 \\
$\mathbf{0 . 7}$ & 12,250 & 15,400 & 0.54 & 0.48 \\
$\mathbf{0 . 8}$ & 20,000 & 25,000 & 0.67 & 0.62 \\
$\mathbf{0 . 9}$ & 30,000 & 44,000 & 0.89 & 0.87 \\
\hline
\end{tabular}

Note: Severance pay factor $=$ amount of severance pay / (gross monthly wage $*$ tenure) 


\section{IZA Discussion Papers}

\begin{tabular}{|c|c|c|c|c|}
\hline No. & Author(s) & Title & Area & Date \\
\hline 861 & $\begin{array}{l}\text { Y. L'Horty } \\
\text { C. Rault }\end{array}$ & $\begin{array}{l}\text { Inflation, Minimum Wage and Other Wages: An } \\
\text { Econometric Study on French Macroeconomic } \\
\text { Data }\end{array}$ & 1 & $08 / 03$ \\
\hline 862 & $\begin{array}{l}\text { J. T. Addison } \\
\text { C. R. Belfield }\end{array}$ & Union Voice & 3 & $08 / 03$ \\
\hline 863 & C. U. Chiswick & $\begin{array}{l}\text { Immigrant Religious Adjustment: An Economic } \\
\text { Approach to Jewish Migrations }\end{array}$ & 1 & $08 / 03$ \\
\hline 864 & $\begin{array}{l}\text { D. Cobb-Clark } \\
\text { C. Ryan } \\
\text { R. Breunig }\end{array}$ & $\begin{array}{l}\text { A Couples-Based Approach to the Problem of } \\
\text { Workless Families }\end{array}$ & 6 & $08 / 03$ \\
\hline 865 & S. W. Polachek & $\begin{array}{l}\text { Mincer's Overtaking Point and the Lifecycle } \\
\text { Earnings Distribution }\end{array}$ & 5 & $08 / 03$ \\
\hline 866 & A. Constant & $\begin{array}{l}\text { Immigrant Adjustment in France and Impacts on } \\
\text { the Natives }\end{array}$ & 1 & $08 / 03$ \\
\hline 867 & $\begin{array}{l}\text { T. J. Dohmen } \\
\text { B. Kriechel } \\
\text { G. A. Pfann }\end{array}$ & $\begin{array}{l}\text { Monkey Bars and Ladders: The Importance of } \\
\text { Lateral and Vertical Job Mobility in Internal } \\
\text { Labor Market Careers }\end{array}$ & 1 & $08 / 03$ \\
\hline 868 & $\begin{array}{l}\text { P. Brañas Garza } \\
\text { S. Neuman }\end{array}$ & $\begin{array}{l}\text { Analyzing Religiosity Within an Economic } \\
\text { Framework: The Case of Spanish Catholics }\end{array}$ & 5 & $08 / 03$ \\
\hline 869 & $\begin{array}{l}\text { A. B. Krueger } \\
\text { A. Mas }\end{array}$ & $\begin{array}{l}\text { Strikes, Scabs and Tread Separations: Labor } \\
\text { Strife and the Production of Defective } \\
\text { Bridgestone/Firestone Tires }\end{array}$ & 3 & 09/03 \\
\hline 870 & $\begin{array}{l}\text { S. Klasen } \\
\text { A. Launov }\end{array}$ & $\begin{array}{l}\text { Analysis of the Determinants of Fertility Decline } \\
\text { in the Czech Republic }\end{array}$ & 4 & 09/03 \\
\hline 871 & $\begin{array}{l}\text { Y. L'Horty } \\
\text { C. Rault }\end{array}$ & $\begin{array}{l}\text { The Impact of Growth, Labour Cost and Working } \\
\text { Time on Employment: Lessons from the French } \\
\text { Experience }\end{array}$ & 5 & 09/03 \\
\hline 872 & $\begin{array}{l}\text { J. R. Munch } \\
\text { M. Rosholm } \\
\text { M. Svarer }\end{array}$ & Are Home Owners Really More Unemployed? & 1 & 09/03 \\
\hline 873 & $\begin{array}{l}\text { M. Falk } \\
\text { B. M. Koebel }\end{array}$ & $\begin{array}{l}\text { The Impact of Office Machinery and Computer } \\
\text { Capital on the Demand for Heterogeneous } \\
\text { Labour }\end{array}$ & 5 & $09 / 03$ \\
\hline 874 & J.-S. Pischke & $\begin{array}{l}\text { The Impact of Length of the School Year on } \\
\text { Student Performance and Earnings: Evidence } \\
\text { from the German Short School Years }\end{array}$ & 6 & $09 / 03$ \\
\hline 875 & C. Grund & $\begin{array}{l}\text { Severance Payments for Dismissed Employees } \\
\text { in Germany }\end{array}$ & 3 & $09 / 03$ \\
\hline
\end{tabular}

An updated list of IZA Discussion Papers is available on the center's homepage www.iza.org. 